\title{
Determinants of Cocoa (Cacao Theobroma) Farmers Uptake of Crop Insurance: Evidence from Ekiti State
}

Olatomide Waheed Olowa (Corresponding Author)

Department of Agricultural Education Federal College of Education (Technical) Akoka P. O. Box 269 Yaba, Lagos, Nigeria

Email: owolowa@gmail.com

\section{Omowumi Ayodele Olowa}

Department of Agricultural Education Federal College of Education (Technical) Akoka P. O. Box 269 Yaba, Lagos, Nigeria

\author{
Article History \\ Received: June 15,2020 \\ Revised: July 18, 2020 \\ Accepted: July 25, 2020 \\ Published: July 31, 2020 \\ Copyright (C) 2020 ARPG \\ \& Author \\ This work is licensed \\ under the Creative \\ Commons Attribution \\ International \\ (c) (1) $C C$ \\ BY: Creative Commons
}

Attribution License 4.0

\begin{abstract}
Cocoa farmer faces increasing challenging environment through exposure to risks factors which have impacted negatively on their production or output. Since farmers are primary producers and often times lack capacity to control risks factor, it is important to manage this factors. This study examines the cocoa farmers' risk preferences and crop insurance perception and isolates the drivers of decision to uptake crop insurance among cocoa farmers in Ekiti state. The sample for the study consist of 200 cocoa farmers who were household heads selected through multi-stage sampling across four Local government areas of Ekiti State who are predominantly cocoa producers. Data collected on sociodemographic characteristics, perception of crop insurance and risk preferences, were analyzed using descriptive statistics and binary logistic model. Results showed that majority of the cocoa farmers were without crop insurance, with higher enrolment in Membership of cooperative society, owned their land, larger household size and lower educational level but higher level of farm experience when compared to cocoa farmers who are holding crop insurance. Farmers risk preferences showed no significant difference between farmers with or without insurance. Education $(\beta=0.59)$, Household size $(\beta=0.0029)$ and Debt use $(\beta=0.02)$, Membership of cooperative $(\beta=-4.53)$, Farming Experience $(\beta=-2.51)$, Owned Land $(\beta=-2.19)$ and Non-Farm Income $(\beta=-0.65)$ were among the significant determinants of insurance uptake. Risk mitigating measures such as provision of necessary incentives such as improved varieties of cocoa seedling, as well as provision of fertiliser and approved pesticides, financial assistance, and simple processing technologies that produce standard cocoa bean plus a re-jigged Nigeria Agricultural Insurance Corporation (NAIC) for an improved discharge of its function are recommended.
\end{abstract}

Keywords: Cocoa farmers; Crop insurance; Risk preferences; Risk management; Ekiti state.

\section{Introduction}

Nigeria is one of the largest global producer of cocoa, literally behind the two first producing contries in Africa which are Cote de voire, and Ghana. In terms of exportation, Nigeria is the 3rd largest African exporter, after Cote de voire and Ghana. Average annual Cocoa production rate was 420,000 tonnes in the "60s which fell to 170,000 tonnes in 1999. Production climbed to 389,272 tonnes between 2000 and 2010, but fell back to 192,000 tonnes in 2015 and 2016. After dropping to fourth place, Nigeria is now the sixth largest producer globally.

Cocoa is a household cash crop and key agriculture produce in Nigeria. It is used for local consumption and is also exported which generates foreign exchange for the country. According to statistics, Nigeria produced 367,000 tonnes of Cocoa in 2017.The export data from 2017 shows that Nigeria exported 161,285.72 metric tonnes of agricultural produce. Cocoa export accounted for 33,294 out of this figure (NEPC, 2018).

Cocoa has been the leading agricultural export of the country with states such as Edo, Oyo, Osun, Ondo, Ogun, Cross River, Akwa Ibom, Ekiti, and Delta known as the cocoa producing States in Nigeria. Cocoa production is traditionally for export, with less than $10 \%$ utilised for cocoa products like cocoa butter, cocoa biscuit, cocoa liquor, chocolates, etc. However, a sizable quantity is processed to create value addition to the export or for local industries as their main raw materials. According to Nigerian Export Promotion Council (NEPC) (2014), the value of cocoa exports amounted to a total $\$ 666.45 \mathrm{~m}$. On the international market, the demand for cocoa is increasing due to the boom in the chocolate consumption, aside other uses of cocoa, whereas the cocoa production is declining from the producing states. From the production estimates of ICCO [1], global cocoa production has decreased from 4.3 million metric tonnes in 2010/2011 to 4.0 million metric tonnes in 2011/2012 and 3.9 million metric tonnes in 2012/13. ICCO forecasts a shortfall of about 50,000 tons in 2013. This may not be unconnected with various risk factors affecting cocoa production at various local farms strewn across developing countries. 
Various studies on cocoa production and marketing have revealed that cocoa sector in Nigeria is faced with a number of risks and uncertainties [2,3]. The prices of cocoa has also been decreasing mainly due to stock/grind ratios, global food prices, and fragmentation in cocoa trade and processing industries [4]. It has also been estimated that around $30 \%$ of the cocoa crop world-wide is lost to pest and disease attack [5]. Such attacks reduce cocoa productivity and hence lower the supply for both the internal and international markets. Chemical treatment is however not always possible, due either to the nature of the pests or because the chemicals are too expensive for most farmers and lower the international standard of the beans as a result of contamination. The heavy use of pesticidesis also compounded by their contribution to environmental pollution and health risks to farmers [5]. The farmers also lack information into market trend for cocoa prices. The Issues of price volatility, yield reduction over the years, small holding farms that are not economical, and lucrative nature of alternative crops such as rubber are making cocoa farmers to abandon their cocoa farms. The consequences of price volatility, together with increasing production costs, have been contributing to economic insecurity and impoverishment for millions of cocoa farmers [6]. These are all factors contributing to risks and future uncertainties of cocoa and therefore need serious attention. Risk being the probability attached to the occurrence of the uncertain events of a production or investment decision by a farmer, presents non-determinate probability of occurrence of these events as it is beyond ordinary human control, that is, the probabilities of the possible outcomes are unknown [7].

Risk management involves choice among existing mitigating alternatives to reduce the effect of risk [8]. A variety of risk management strategies exist. These include enterprise diversification, insurance, forward marketing techniques such as future options and cash forward contracts, sequential marketing, direct sales to consumers, controlling and limiting debt, off-farm work and investments, controlling family consumptions, strategic business planning, keeping cash at hand, and the use of extension services and farmers' cooperatives [8-10].

One of the solutions that producers can use to mitigate their risks is crop insurance which aims at protecting farmers against various risks like low crop yields, unpredictable rainfall, poor prices, and loss of livestock [11]. Agricultural insurance products come in arrangement that might be different from one another [11, 12]. The range of agricultural policies can be classified into three categories namely: Specific or named peril products, All-risk or multi-peril products and Index-based products. The Specific or named peril products is the insurance, which is common in Western Europe and in Sweden. It covers the losses from a specific threat such as hail or fire, and is mainly offered by private companies. All-risk or multi-peril products provide crop insurance coverage for many types of perils, but there is no specification of perils [13]. Index- based products: is a product that the farmers use to protect their crops and the compensation is based on a weather, area or satellite growth index [14].

Index-based insurance has proven to be less successful. The compensation for loss is hardly ever consistent with the farmer's actual loss. Crop Insurance falls under the All-risk or multi-peril products and it is marketed by the Nigerian Agricultural Insurance Corporation (NAIC) which was established in 1978. However, there have been negative perception of insurance by farmers in Nigeria which have emanated from issues such as asymmetry of information, unfair loss adjustment procedures, biases in setting premium as well as poorly designed policies are major causes of cocoa farmer's lack of interest. Evidence from literature further shows that farmer's demand for these new products has been surprisingly low $[15,16]$, with the limited access to insurance products being explained as being lack of trust by farmers in insurance providers as well as lack of farmer understanding about new and complex insurance products. Despite the fact that these programs are considered important in reducing cocoa farmers' risk, some farmers tend to adopt crop insurance innovations while others may seem not to. Since there is still little empirical attention in the literature about the demand of insurance by cocoa farmers in Nigeria, this study seek to fill the gap Hence, understanding the factors that affect purchase of crop insurance is important.

Studies on determinants of Crop Insurance with respect to Nigeria are very scanty or totally unavailable. Few available studies on risk and cocoa production focused majorly on either the coping strategies or cost and returns on cocoa. Few studies available on crop insurance with respect to cocoa production are foreign-based with study areas being United Kingdom (UK) and Australia these studies use a combination of qualitative and quantitative consumer research techniques to highlight a complex array of farmers' attitudes, values, and preferences towards risks and crop insurance. The following factors have been commonly identified as the main factors in determining farmer's decision to hold insurance: One, Age, education and experiences: Older farmers with a higher level of experience and education are more positive to insurance and sophisticated methods to risk management [17]. This can lead to better precision in risky situation and changes in risk preferences for an improved risk carrying capacity. This group of policyholders has more experience and use more sophisticated methods to calculate risk and possible outcomes. A high level of education and experience indicate more sophisticated risk management tools. Two, Farm size: Farmers who have larger average acres have higher risk exposure and tend to use crop insurance more often [18]. The reasons are unconnected with the managing capacity and utilized economies of scale [17]. Farmers with more hectares have a greater yield requirement and possible debt liability. These certainly are sufficient reasons to seek insurance coverage. Large farms also sometimes take large investments that increase the rate of return in order to pay offs any rates, since the risk exposure may increase. Three, Debt use: Farmers with a high debt ratio use insurance more frequently [17]. The reason is the exposure to financial risk that requires a higher level of yield to secure the ability to pay financial costs. Four, Land tenure: Farmers with a high level of ownership of land tend to have a greater stability in access to land [17]. They have a higher wealth level and therefore less likely to be exposed to financial risk and therefore have less incentive to carry insurance. Farmers with a lower share of tenured land have a greater need for insurance. Five, Geographic position and local conditions: The geographic position affects what kind of climate the crops are exposed to [19]. The local conditions for example what type of soil and water needs influence the crop insurance decisions [17]. Six, Off-farm income: Off-farm income can be expected to stabilize the overall 
income from the livestock and crop production [17]. Off-farm income can be viewed as a diversification tool in the agricultural sector. Barry, et al. [17], found that off-farm income did not have any positive impact with the decision to insure. Seven, Expected yield: The expected yield may be assessed by asking the farmers about their subjective perception about the yield level [20]. Shaik, et al. [20], find that farmers that perceive a high level of expected yield are less willing to purchase crop insurance. The differences in expected yield may indicate variations in soil quality and management skills [17]. Farmers with high expected yield also have a higher expected income. Differences in these factors may indicate differences in yield risk, which may affect insurance use. Eight, Perceived yield risk: The farmers have a greater risk to be subject to negative weather, pests or deceases $[19,21]$. Farmers that perceived a higher level of yield risk are also more willing to purchase crop insurance [20]. In this case, it is also interesting to examine which factors/risks that affect production risk the most [19]. Nine, Diversification: There are other ways the purchasing insurance to manage production risk [22]. Farmers may diversify their business in many ways for example by off-farm income, number of crops grown, hedging and increase the number of enterprises on the farm. Diversification is one way to decrease risk exposure. Adinolfi, et al. [18], show that a high degree of diversification is associated with a low degree of insurance use. Ten, Risk preferences: Risk preferences affect the choice to purchase crop insurance [17]. According to the expected utility theory [23], Farmers are normally risk averse and such an individual strive to reduce risk [7]. Eleven, Insurance perceptions: The properties of the insurance have an impact on if the farmer purchases crop insurance [24]. Farmers may desire crop insurance that offers a greater flexibility in the choice of insurance. In addition, the cost of the insurance is important. Adinolfi, et al. [18], as well as Smith and Baquet [25] have also found that the premium rate of the insurance is one important factor for the farmers choice of crop insurance. It is critical to have low cost of production to be comparative in a commodity industry It is these identified gaps in the literature that this study seek to address by analysing, in the first instance, risks, risk preferences and insurance perception in cocoa production. In the second instance, the factors determining the factors that influence cocoa farmers' uptake of crop insurance and farmers that are insured.

So in the study, several questions about the framers crop insurance perspective were asked. Selection of variables included in the estimated logit model to determine the drivers of holding crop insurance by cocoa farmers were based on the foregoing.

\section{Methodology}

\subsection{Study Area}

Cocoa is produced in the rainforest zone of Nigeria, within the area known as Cocoa Belt. The main cocoa producing States located within this belt include Akwa Ibom, Cross River, Delta, Edo, Ekiti, Ogun, Ondo, and Oyo. Among these States, Ekiti State, located in Southwest Nigeria with a total area of $6,353 \mathrm{~km}^{2}$ produces over $40 \%$ of the cocoa of the famous old western state. The study was therefore conducted in Ekiti State. The State is typically an agrarian society due to its favourable ecological and climatic conditions. The climate of the State is tropical monsoon with two distinct seasons - the rainy season (April-October) and dry season (November-March). Humidity is high during the rainy season and low during the Harmattan period of the dry season. The vegetation of the State ranges from tropical forest in the south, to savannah in the northern pheripheries.

\subsection{Data Collection}

The study is a survey of cocoa farmers sampled at household level. Primary data used for the study was collected through administration of structured questionnaire. The questionnaire was structured to collect information on socio-economic characteristics of cocoa farmers in selected local governments in Ekiti State and risk associated with cocoa production. Specifically, for the production of cocoa, the questionnaire was structured to collect information on the area of cocoa farms and how the farmers obtained the land on which the farms are existing; type of cultural practices adopted in improving the yield of their cocoa trees, most especially fertilizer application; and type of labour employed by the farmers on their cocoa farms. The questionnaire also contained a number of predetermined lists of risks for the farmers to indicate the one that is most applicable to their production of the cocoa. Also, the farmers' crop insurance perceptions, risk attitude and risk preferences were compiled. Likert scale was used to define the farmers' crop insurance and their risk preferences. Hence, consequently most of the questions and statements in the survey were formulated as a Likert-type with a five point scale, where 1 is strongly disagree and 5 is strongly agree with the statement. The most frequently risks mentioned by the farmers and risk preferences were then compiled for the final questionnaire.

\subsection{Sample and Sampling Techniques}

Multistage sampling technique was adopted for the selection of the Cocoa farmers. In the first stage, four local government areas were chosen from Ekiti State and these include: Irepodun/Ifelodun, Gbonyin, Ekiti West and Ijero. Virtually, all the local communities within these LGAs are involved in cocoa production. Therefore, in the second stage, two communities were randomly selected from each of the LGAs for the survey. The selected communities include Awo and Afao in Irepodun/Ifelodun; Ijan and Ilumoba in Gbonyin; Erijinyan and Aramoko in Ekiti West; and Ipoti and Odo Owa in Ijero. In the third stage, Systematic random sampling was then used to reach 200 Cocoa farmers, through random route procedure where enumerators first interviewed Cocoa farmers on one side of the road (left) before moving to the other side (right). Thus, for each of the major roads in the communities, the third houses on the left and right were sampled in order to ensure unbiased selection of respondents. In each of the households, 
the questionnaire was administered to the heads that owned cocoa plantation. Data generated from the questionnaire administered in the eight selected communities were pooled together for the final analysis.

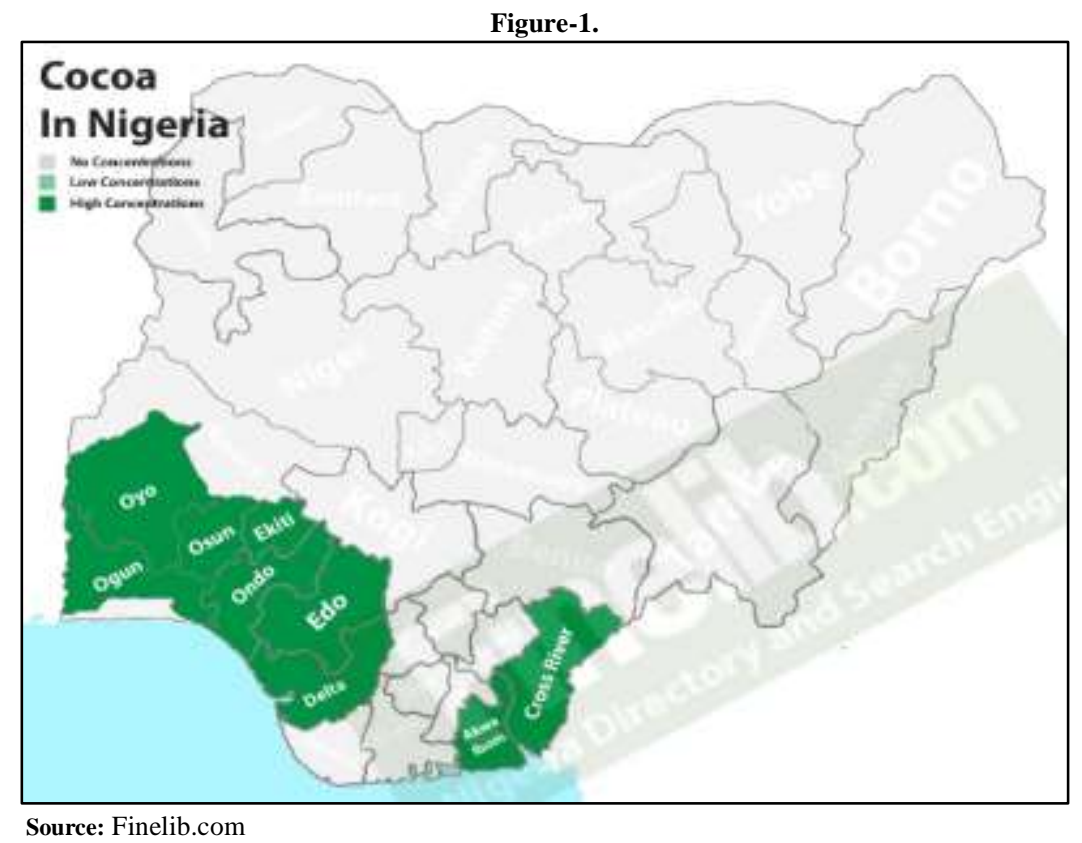

\subsection{Data Analysis}

Descriptive statistics such as mean and Percentage were used to summarized the socio- economic characteristics of sampled Cocoa farmers in the study area while binary logit was used to determine the factors that influence cocoa farmers' uptake of crop insurance and farmers' that are insured.

\subsection{T-test}

A T-test is conducted to evaluate if there are any statistically significant differences in every single attribute. This test is aimed to give a descriptive overview of the statistical variables to analyze. The basic hypothesis is that the variances differ and that two independent samples exist where the observations are normally distributed [26].

The population variances $\sigma_{x}^{2}$ and $\sigma_{Y}{ }^{2}$ is estimated by the sampling variance $S_{x}{ }^{2}$ and $S_{Y}{ }^{2}$

The population mean value $\mu \mathrm{x}$ and $\mu \mathrm{y}$ is estimated by the sample mean values of $\mathrm{X}$ and $\mathrm{Y}$. The significant level is $\alpha$ and $\mathrm{D} 0=0$

The null hypothesis is that $\mathrm{H} 0: \mu \mathrm{x}-\mu \mathrm{y}=0$ which is tested against the alternative hypothesis $\mathrm{H} 1: \mu \mathrm{x}-\mu \mathrm{y} \neq 0$. The decision rule is:

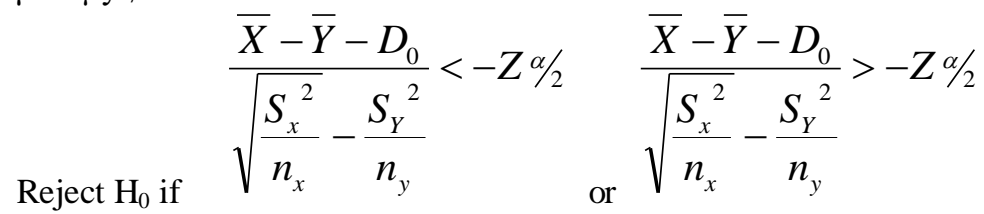

$\mathrm{n}_{\mathrm{x}}$ and $\mathrm{n}_{\mathrm{y}}$ relate to the sampling size for $\mathrm{X}$ and $\mathrm{Y}: \mathrm{Z} \alpha / 2$ relate to a value from the normal distribution table where the probability for the outcome is 2 [26]. This statistical test compare the mean value for an observed factor between farmers with insurance, $\mathrm{X}$, and without insurance, $\mathrm{Y}$.

\subsection{Logit Model}

To be able to analyze how the entire set of the variables affect the decision to purchase an insurance or not, logistic regression was used. The method estimates the probability for a yes or no outcome [27]. The dependent variable is binary with value $\mathrm{Y}=1$ for having an insurance and $\mathrm{Y}=0$ for not having an insurance. Several independent variables $\mathrm{X}$, according to the model affect the outcome of $\mathrm{Y}$. Hence, the variation in the $\mathrm{X}$ variable affects the probability of the outcome of $Y$, see equation 2 :

$$
\mathrm{P}(\mathrm{Y}=1)=\mathrm{F}\left(\beta^{\prime} X\right)
$$

Where,

$P=$ the probability

$Y=$ the dependent variable, insurance or not.

$\beta=$ factors, $(\beta 1 \ldots . . . \beta n)$

$X=a$ vector of observed variables $\left(x_{1} \ldots \ldots x_{n}\right)$. That consist of for example farm size, production, age and risk preference. 
The probability for $\mathrm{Y}=0$ is $\mathrm{P}(\mathrm{Y}=0)=1-\mathrm{F}\left(\beta^{\prime} X\right)$

When the cumulative distribution factor $\mathrm{f}\left(\beta^{\prime} x\right)$ form the logistic equation as in equation 4 [26]:

$$
P(Y-1)=\frac{\ell^{\beta^{\prime}{ }_{X}}}{\left(1+\ell^{\beta^{\prime}{ }}\right)}
$$

Where $\mathrm{P}(\mathrm{Y}=1)$ is the related probability to $\mathrm{Y}=1$

\section{Results and Discussion}

\subsection{Descriptive}

Table 1 summarised the descriptive analysis of socio economic variables of sampled cocoa farmers. The average age of farmers with crop insurance was 51.3 years and those without was 56.4 years. The years of experience for being a cocoa farmer differs. Cocoa Farmers without crop insurance were more experienced than those with insurance in all the ranges. For instance, three-quarter of farmers who claimed to have between 31 and 45 years of experience were without insurance. The size of majority of the cocoa plantations ranged between 6 and 15 hectares, meaning that majority of the production was at small scale level, however, cocoa farmers without insurance have a greater proportion (hectares) of cocoa farms compared with their counterparts who have insurance. Furthermore, farmers without crop insurance were more (66\%) than farmers who claimed to have crop insurance (34\%). Majority of the cocoa farmers were males $(86 \%)$ with barely little difference between those with crop insurance $(40 \%)$ and those without crop insurance $(46 \%)$.

Table-1. Socio economic characteristics of cocoa farmers $(n=200)$

\begin{tabular}{|c|c|c|c|}
\hline Variables & Insurance & No Insurance & Mean \\
\hline \multicolumn{4}{|l|}{ Gender (\%) } \\
\hline Male & 40 & & 46 \\
\hline Female & 6.0 & & 8.0 \\
\hline \multicolumn{4}{|l|}{ Marital status (\%) } \\
\hline Single & 3.0 & & 4.0 \\
\hline Married & 40 & 49 & \\
\hline Divorced & 0 & 0.0 & \\
\hline Widowed & 3.0 & 1.0 & \\
\hline Age (Mean) & 51.3 & 56.4 & \\
\hline Household size (Mean) & 5.6 & 8.2 & 5.9 \\
\hline \multicolumn{4}{|l|}{ Non-Farm income } \\
\hline Yes & 38 & & 105.0 \\
\hline no & 42 & 15.0 & \\
\hline Education (\%) & & & 9.0 \\
\hline Primary & 33.0 & 18.0 & \\
\hline Secondary & 10.0 & 4.0 & \\
\hline Tertiary & 5.0 & 0.0 & \\
\hline No formal & 12.0 & 38.0 & \\
\hline \multicolumn{4}{|c|}{ Membership of cooperative (\%) } \\
\hline Member & 11.0 & 50.0 & \\
\hline Non-member & 29.0 & 10.0 & \\
\hline Farming experience & & & 16.0 \\
\hline $1-15$ & 13.0 & 25.0 & \\
\hline $16-30$ & 6.0 & 16.0 & \\
\hline $31-45$ & 11.0 & 30.0 & \\
\hline Insurance Use (\%) & 34.0 & 66.0 & 47.0 \\
\hline \multicolumn{4}{|c|}{ Land Ownership Status (\%) } \\
\hline Owned Land & 34.0 & 43.0 & \\
\hline Rented/Lease & 0.0 & 23.0 & \\
\hline Debt Use (\%) & 64.0 & 36.0 & 43.0 \\
\hline \multicolumn{4}{|l|}{ Sources of Debt (\%) } \\
\hline Cooperative & 28.0 & 30.0 & \\
\hline Commercial Bank & 0.0 & 0.0 & \\
\hline Anchor Scheme (CBN) & 30.0 & 0.0 & \\
\hline Money Lender & 6.0 & 6.0 & \\
\hline Cocoa Farm Size (Ha) & & & 5.6 \\
\hline $1-5$ & 2.3 & 1.9 & \\
\hline $6-10$ & 18.0 & 27.8 & \\
\hline $11-15$ & 15.3 & 28.0 & \\
\hline $16-20$ & 2.0 & 4.7 & \\
\hline
\end{tabular}


The mean household size for farmers without crop insurance was higher $(8.2 \%)$ than those without crop insurance $(5.6 \%)$. Analysis of land ownership status revealed that majority of the cocoa famers $(77 \%)$ owned the land upon which cocoa grows whether through purchase or inheritance. While the remaining $23 \%$ indicated that they rented or lease the land. The analysis further revealed that among those who owned their land, $43 \%$ were without crop insurance while $23 \%$ were with crop insurance. All those who rented or lease land were without insurance. In terms of debt use or borrowed capital for production, majority of those who borrowed capital for production were cocoa farmers with crop insurance (64\%) while the remaining (36\%) were without insurance. Among those who are indebted in the course of cocoa production, majority of them $(58 \%)$ are indebted to or got their loan from cooperative while $30 \%$ are indebted to anchor borrower scheme of the Central Bank of Nigeria. Cocoa farmers without crop insurance were in the majority of those got their loan from Cooperative $(30 \%)$ when compared with cocoa farmers without insurance $(28 \%)$. All cocoa farmers who secured loan from anchor borrower scheme were those with crop insurance. Perhaps crop insurance gives an edge to securing institutional loans. Moreover, majority of Cocoa farmers without crop insurance were in membership of cooperative (60\%) compared to their counterpart (40\%). Membership of cooperative seems to be a form of respite or option against taking up insurance policy.

In Table 2, sources of risks to cocoa production, farmers risk preferences and their perception of insurance as risk mitigating measure were analysed. The statistical analysis is based upon a T-test where each single variable impact on the crop insurance decision was evaluated. The impact from other factors were not evaluated in this test. Cocoa farmers revealed their subjective perception concerning what major type of production risk that causes a reduced yield. Among the sources of production risk variables, there are statistical significance difference in the mean of drought, flood, Pest and diseases, Lack of subsidies, Input price, weak extension and high cost of production between the user and non-user crop insurance. Soil and sand drift, Natural weather effects, traditional method of farming, High maintenance of the farm, Poor productivity and Technical Capacity/knowledge in production process have been mentioned in literature as significant sources of risk, but here, were not significant [3, 28].

Table-2. Risks, Risk Preferences and Insurance Perception in Cocoa Production in Ekiti State

\begin{tabular}{|c|c|c|c|}
\hline Sources of risks/Preference/Perception & $\begin{array}{l}\text { Mean - } \\
\text { Insurance }\end{array}$ & $\begin{array}{l}\text { Mean - No } \\
\text { Insurance }\end{array}$ & T-Test \\
\hline \multicolumn{4}{|l|}{ Sources of Risk } \\
\hline Drought & 2.3 & 2.1 & $2.49 * *$ \\
\hline Flood & 1.1 & 1.3 & $2.22 * *$ \\
\hline Soil and sand drift & 1.2 & 1.3 & $1.35 \mathrm{e}$ \\
\hline Pests and diseases & 3.5 & 3.3 & $3.78 * * *$ \\
\hline Natural weather effects & 3.3 & 3.1 & $1.43 \mathrm{e}$ \\
\hline Lack of subsidies on agrochemicals & 2.4 & 3.1 & $2.11 * *$ \\
\hline Price of inputs & 3.7 & 3.5 & $4.22 * * *$ \\
\hline Traditional methods of farming & 2.5 & 2.2 & $1.12 \mathrm{e}$ \\
\hline Weak research and extension linkages & 3.5 & 2.8 & $2.31 * *$ \\
\hline High maintenance of the farm & 2.6 & 2.3 & $1.54 \mathrm{e}$ \\
\hline High cost of production & 3.2 & 3.5 & $245 * *$ \\
\hline Poor productivity & 2.5 & 2.7 & $1.14 \mathrm{e}$ \\
\hline Technical Capacity/knowledge in production process & 2.5 & 2.8 & $1.32 \mathrm{e}$ \\
\hline \multicolumn{4}{|l|}{ Risk Preferences } \\
\hline I like having my farm exposed to risk & 2.6 & 2.5 & $1.23 \mathrm{e}$ \\
\hline $\begin{array}{l}\text { I am willing to expose myself to greater risk in } \\
\text { order to increase the yield of my crop }\end{array}$ & 3.0 & 2.7 & $2.11 * *$ \\
\hline I prefer to be safe than sorry in my business & 3.3 & 3.1 & $2.43 * *$ \\
\hline $\begin{array}{l}\text { I strongly prefer to acquire sustainable gains than avoiding } \\
\text { losses in my cocoa farm }\end{array}$ & 2.6 & 2.5 & $1.25 \mathrm{e}$ \\
\hline $\begin{array}{l}\text { I am willing to take higher risks in order } \\
\text { to achieve a higher payoff }\end{array}$ & 3.1 & 3.0 & $4.52 * * *$ \\
\hline \multicolumn{4}{|l|}{ Insurance Perception } \\
\hline $\begin{array}{l}\text { Crop insurance is important because of debt and rent } \\
\text { payment obligations }\end{array}$ & 2.4 & 1.8 & $2.31 * *$ \\
\hline I am well aware of the crop insurance provisions & 3.4 & 2.2 & $2.42 * *$ \\
\hline $\begin{array}{l}\text { Crop insurance is an important risk management tool } \\
\text { in my production }\end{array}$ & 3.1 & 1.6 & $2.44 * *$ \\
\hline $\begin{array}{l}\text { Per-hectare premium costs are very important to my crop } \\
\text { insurance decision }\end{array}$ & 3.2 & 3.2 & $2.21 * *$ \\
\hline Availability of high coverage levels is important to me & 3.3 & 2.1 & $2.37 * *$ \\
\hline $\begin{array}{l}\text { The ability to insure different acreages separately is } \\
\text { Important }\end{array}$ & 3.4 & 3.0 & $2.29 * *$ \\
\hline $\begin{array}{l}\text { Crop insurance is not important for me because my yield } \\
\text { per hectare already is low }\end{array}$ & 1.8 & 3.8 & $2.18^{* *}$ \\
\hline Crop insurance provides good protection to my yield & 3.5 & 2.2 & $2.49 * *$ \\
\hline
\end{tabular}

**Pvalue $<0.05$ and $* * *<0.01 . \mathrm{e}=$ not significant 
Risk preferences in Table 2, are based on farmers response to statements about risk preferences. From the table, Cocoa farmers who have crop insurance have higher average response and agreed with all the statements to a higher extent than those with no crop insurance. It is also remarkable that cocoa farmers with insurance prefer risk in their business to a higher extent than those who are not insured. The differences in mean between farmers with insurances and those without insurances were statistically significant except in two statements namely: "I like having my farm exposed to risk and I strongly prefer to acquire sustainable gains than avoiding losses in my cocoa farm". Also in Table 2, is analysed the differences in perception between cocoa farmers with and without insurance. The perceptions of the insurance product have an impact on the farmers' choice to buy insurance. There are significant differences in the most of the statements. However, premium per hectare does not show any significance in this test. All other statements indicate a high level of significance.

\subsection{Logit Regression}

Table 3 presents the results of the binary logit model. The coefficient values explain the influence of each explanatory variable on the probability of cocoa farmer taking up crop insurance. As shown in Table 3, the performance of the individual explanatory variables included in the model indicate that Age, Gender and Farm Hectare do not significantly influence the insurance uptake in the study area. Out of the ten independent variables fitted, seven turned out to be the main determinant of cocoa farmers' uptake of crop insurance namely, Education, Household size, Non-Farm Income, Membership of cooperative, Farming Experience, Owned Land and Debt use.

Table-3. Factors Affecting Cocoa Farmers' uptake of Crop Insurance

\begin{tabular}{l|l|l}
\hline Factors & Coefficient & P-value \\
\hline CONSTANT & $-0.684^{* *}$ & 0.010 \\
& $(0.266)$ & \\
\hline Age & 0.3456 & 0.507 \\
\hline Education & $0.595^{* *}$ & 0.03 \\
& $(0.274)$ & \\
\hline Household size & $0.0029293^{* * *}$ & 0.001 \\
& $(0.00285)$ & \\
\hline Non-Farm Income & $-0.658^{* *}$ & 0.068 \\
& $(0.360)$ & \\
\hline Gender & 0.0763423 & 1.19326 \\
\hline Membership Cooperative & $(0.00067)$ & 0.000 \\
\hline Farming Experience & $-4.530^{* * *}$ & \\
\hline Owned Land & $(0.481)$ & 0.0034 \\
\hline Debt Use & $-2.51599^{* * *}$ & 0.000 \\
\hline Farm Hectare & $-2.19365^{* * *}$ & \\
\hline McFadden Pseudo-R ${ }^{2}=0.0878$. & $(0.0012)$ & 0.048 \\
\hline
\end{tabular}

Notes: Standard errors shown in parentheses. Statistical significance levels: $* * * 1 \%, * * 5 \%$ and $* 10 \%$.

While Education $(\beta=0.59)$, Household size $(\beta=0.0029)$ and Debt use $(\beta=0.02)$ were positively significant, the remaining four variables namely Membership of cooperative $(\beta=-4.53)$, Farming Experience $(\beta=-2.51)$, Owned Land $(\beta=-2.19)$ and Non-Farm Income $(\beta=-0.65)$ were negative and significant. Positive coefficients indicates that the higher values of the variables higher values correspond to a higher probabilities that cocoa farmer's uptake of insurance. The reverse is the case for negative coefficients. The positive significance of Education suggests that the likelihood of crop insurance uptake increases with increase in education. This outcome agrees with the conclusion of Barry, et al. [17] that older farmers with a higher level of experience and education are more positive to insurance and sophisticated methods to risk management. Similarly, Household size is associated with higher probability of a cocoa farmer uptake of crop insurance. In other words, crop insurance uptake increases with increase in household size. This is plausible as insurance is a form of security against risk that are capable of wiping out farm where daily sources of living and family maintenance are eke out. Thus the survival instinct would engender making provision for indemnification against the unexpected as concern for increasing family size subsist. The positively significant Debt use indicates that with increasing debt burden, cocoa farmers are more likely to purchase crop insurance. According to Barry, et al. [17], Farmers with a high debt ratio use insurance more frequently. The reason is that exposure to financial risk requires a higher level lowest of yield to secure the ability to pay financial costs. On the other hands, the coefficients of Membership of cooperative, Farming Experience, Owned Land and Non-Farm Income were negative and significant. The negative sign on coefficient of Membership of cooperative society suggests the likelihood of crop insurance uptake decreases with membership of cooperative. In other words membership of cooperative society will serve to make cocoa farmer not to be willing to purchase crop insurance. Similarly, Farming Experience have negative sign indicating that higher level of farm experience is associated with decrease likelihood to purchase insurance. This outcome negates literature. For instance, Barry, et al. [17] concluded 
that farmers with a higher level of experience are more positive to insurance and sophisticated methods to risk management. Farmer owning land as opposed to leasing or renting is associated with decrease likelihood to purchase crop insurance. This outcome corroborate the assertion of Barry, et al. [17] that Farmers with a high level of ownership of land tend to have a greater stability in access to land. They have a higher wealth level and therefore less likely to be exposed to financial risk and therefore have less incentive to carry insurance. Farmers with a lower share of tenured land have a greater need for insurance. Lastly, that Non-Farm income is negatively associated with cocoa farmers' insurance uptake, suggest that availability of other source of income to cocoa farmer is correlated with lower likelihood to carry crop insurance. Barry, et al. [17], states that Off-farm income can be expected to stabilize the overall income from the livestock and crop production. Off-farm income can be viewed as a diversification tool in the agricultural sector. Thus, off-farm income did not have any positive impact with the decision to insure.

\section{Conclusion and Recommendations}

This study examines the factors that influence decision to uptake crop insurance among cocoa farmers in Ekiti State. Ekiti state is at the front row among cocoa producing states in Nigeria. The declining or decreasing cocoa production and changing weather plus numerous literature pointing at increasing risk environment informed the focus of this study. Two hundred cocoa farmers were randomly selected using random route procedure from eight communities which were randomly selected from four Local governments in Ekiti state using the multi-stage sampling technique. The study has shown a number of risks associated with cocoa production in Ekiti state. Five out of all the evaluated production risks among the cocoa farmers namely soil and sand drift, natural weather effects, traditional farming method Poor productivity and technical Capacity/knowledge in production process were not significant. Farmers risk preferences show no significant difference between farmers with or without insurance. This is unexpected because, according to expected utility theory farmers with insurance ought to be more risk averse than other farmers. Risk averse individuals prefer a safe action before an uncertainty occur where the expected monetary outcome is the same for both alternatives. Farmers that choose to purchase insurance have a guarantee that the insurance cover losses if damage occurs on the harvest. The study further shows that perceptions about the insurance product are of importance for the insurance decision. Farmers without insurance perceived that premium, which is the price of insurance per hectare are important. The price of insurance plays significant role on the farmer's choice to purchase crop insurance. If a risk averse cocoa farmer is offered affordable insurance premium he/she would choose to insure. The most important factors that influenced holding crop insurance in the study area were Education, Household size, Debt use, Membership of cooperative, Farming Experience, Owned Land and Non-Farm Income. The findings thus provide policy insights on key areas of intervention in terms of use of crop insurance as risk mitigation strategy in cocoa production. Farmers are primary producers who should not be played down in the risk management arrangements. Concerted efforts to developing convenient risk managing tools in Nigeria should be central in assisting cocoa farmers manage their risks. The government and partners should strive at finding proper ways to improving the terms and conditions of the insurance contracts so as to enable farmers realize the benefits of the scheme. While other financial institution were being re-jigged to meet the modern days challenge, The Nigerian Agricultural Insurance Corporation (NAIC) established in 1978 by the Obasanjo regime has been left moribund and unattended. The consequence of this is that the institution capacity to perform its function in terms of risk mitigation in farming is greatly impeded. There is need to expand the scope of NAIC by creating branches in the rural areas and increase knowledge dissemination about its functions to farmer through rigorous marketing and extension services. Creating pocket friendly crop insurance products as it is found in banking sector will serve as incentive to attract cocoa farmers into up-taking crop insurance. Better production practices against pests and diseases management, and other cultural practices are pertinent in cocoa production system to minimize the threats of unsustainable production. To attain the goals of risks reduction in the face of economic development and poverty alleviation, cocoa farmers should be empowered and assisted with incentives that will allow them to acquire necessary farm inputs in meeting international standards. The farmers need to be taught the current technologies of cocoa production with the provision of necessary incentives such as improved varieties of cocoa seedling, fertiliser and approved pesticides, financial assistance, and simple processing technologies that produce standard cocoa beans. If these are well implemented and monitored, cocoa could become alternative sources of revenue generation and reduce Nigeria's dependent on oil because of the uncertainties in the future of oil as well as its non-renewable nature.

\section{References}

[1] ICCO, 2013. "Production of cocoa beans. The international cocoa organisation (ICCO)." Quarterly Bulletin of Cocoa Statistics, vol. 38, Available: http://www.icco.org/about-us/icco-news/210-november-2012quarterly-bulletinof-cocoa-statistics.html

[2] Hamzat, R. A., Olaiya, A. O., Sanusi, R. A., and Adedeji, A. R., 2006. "State of cocoa growing, quality and research in Nigeria: need for intervention." In A technical presentation at the Biannual Partnership Programme of the World Cocoa Foundation, Brussels, Belgium.

[3] Babalola, F. D., Ayinde, O. E., Chirwa, P. W., and Thiam, D. R., 2016. "Risks and coping strategies of production and marketing of cocoa in Ondo State, Nigeria." Agroforestry Systems, Available: https://link.springer.com/article/10.1007/s10457-016-9905-3

$\begin{array}{lllll}\text { World Cocoa Foundation WCF, 2012. "Cocoa market update." } & \text { Available: } \\ \text { http://worldcocoafoundation.org/wp-content/uploads/Cocoa-Market-Update-as-of-3.20.2012.pdf }\end{array}$


[5] European Union Food Information Council EUFIC, 1999. "A sustainable future for cocoa. FOOD TODAY05/1999." Available: http://www.eufic.org/article/en/food-safety-quality/farmofork/artid/sustainable-future-cocoa/

[6] Make Chocolate Fair MCF, 2013. "Cocoa prices and income of farmers." European Campaign for Fair Chocolate, Available: http://makechocolatefair.org/issues/coco

[7] Hardaker, J., Huirne, R., Anderson, J., and Lien, G., 2004. Coping with risk in agriculture. Cambridge: CABI.

[8] Salimonu, K. K. and Falusi, A. O., 2009. "Sources of risk and management strategies among food crop farmers in Osun State, Nigeria." Afr. J. Food Agric. Nutr. Dev., vol. 9, pp. 1605-1611.

[9] Musser, W. N. and Patrick, G. F., 2002. How much does risk really matter to farmers? In: Just RE, Pope $R D$ (Eds.): A comprehensive assessment of the role of risk in U.S. Agriculture. Boston: Kluwer.

[10] Alimi, T. and Ayanwale, A. B., 2005. "Risk and risk management strategies in onion production in Kebbi State of Nigeria." J. Soc. Sci., vol. 10, pp. 1-8.

[11] Seyed, A. S., Farahnaz, R. G., Seyed, A. S., Yaser, M., Omid, S., and Abass, A., 2010. "Survey of effective factors on adoption of crop insurance among farmers: A case study of Behbahan County." African Journal of Agricultural Research, vol. 5, pp. 2237-2242.

[12] Ankolekar, M. and Janz, K., 2012. Supply and demand side study incl. Product development and subsidies. New Delhi, India: The Micro Insurance Academy.

[13] Raviv, A., 1979. "The design of an optimal insurance policy." The American Economic Review, vol. 69, pp. 84-96.

[14] Smith, V. H. and Glauber, J. W., 2012. "Agricultural insurance in development countries: where have we been and where are we going." Applied Economic Perspectives and Policy, vol. 34, pp. 363-390.

[15] Giné, X. and Yang, D., 2009. "Insurance, credit, and technology adoption: Field experimental evidence from Malawi." Journal of Development Economics, vol. 89, pp. 1-11.

[16] Rue, C. J., 2009. Area-yield crop insurance reconsidered (again): An empirical analysis of demand for area yield insurance for rice farmers in Peru. Davis: University of California.

[17] Barry, P., Ellinger, P., Schnitkey, G., and Sherrik, B., 2004. "Factors influencing farmers' crop insurance decisions." American Journal Agriculture Economics, vol. 86, pp. 103-114.

[18] Adinolfi, F., Capitanio, F., and Enjolras, G., 2012. "The demand for crop insurance: combined approaches for France and Italy." Agricultural Economics Review, vol. 13, pp. 5-22.

[19] The World Bank, 2011. Weather index insurance for agriculture - Guidance for development practitioners. Washington.

[20] Shaik, S., Coble, K., Knight, T., Baquet, A., and Ptrick, G., 2008. "Crop revenue and yield insurance demand: a subjective probability approach." Journal of Agricultural and Applied Economics, vol. 40, pp. 757-766.

[21] Selvaraju, R., 2010. Climate risk assessment and management in agriculture. FAO Rome.

[22] Boehlje, M., Gray, A. W., and Detre, J. D., 2005. "Strategy development in a turbulent business climate concepts and methods." International Food and Agribusiness Management Review, vol. 8, pp. 21-40.

[23] Pindyck, R. and Rubinfeld, D., 2005. Microeconomics. 6th ed. Upper Saddle River.

[24] Barry, P., Ellinger, P., Schnitkey, G., Sherrick, B., and Wansink, B., 2003. "Farmers' preferences for crop insurance attribute." Rewiew of Agricultural Economics, vol. 25, pp. 415-429.

[25] Smith, V. H. and Baquet, A. E., 1996. "Insurance: Evidence from montana wheat farms." American Journal Agricultural Economics, vol. 78, pp. 189-201.

[26] Newbold, P., 1991. Statistics for business and economics. Illinois: Prentice Hall International Inc.

[27] Greene, W., 1993. Econometric analysis. New Jersey: Prentice Hall.

[28] Brånstrand, F. and Fredrik, W., 2014. Factors affecting crop insurance decision: A survey among Swedish farmers. Master thesis in the department of economics. Swedish University of Agriculture. 